\title{
ELECTRON CONCENTRATION AND PHASE STABILITY IN NbCr2-BASED LAVES PHASE ALLOYS
}

\author{
May 12, 1997 \\ Report Prepared by \\ J. H. Zhu and P. K. Liaw \\ The University of Tennessee \\ Department of Materials Science and Engineering

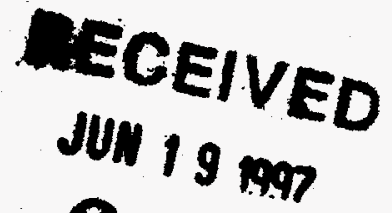 \\ Q \& \\ Knoxville, TN 37996-2200 \\ and \\ C. T. Liu \\ Metals and Ceramics Division
}

Oak Ridge National laboratory, Oak Ridge, TN 37831

under

Subcontract No. ORNL/Sub/93-SP173/02

for

OAK RIDGE NATIONAL LABORATORY

Oak Ridge, Tennessee 37831

Managed by

LOCKHEED MARTIN ENERGY RESEARCH CORP.

for the

U. S. DEPARTMENT OF ENERGY

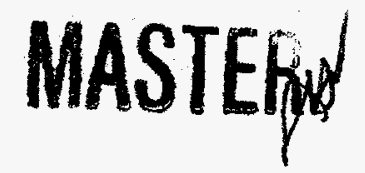

under contract DE-AC05-96OR22464

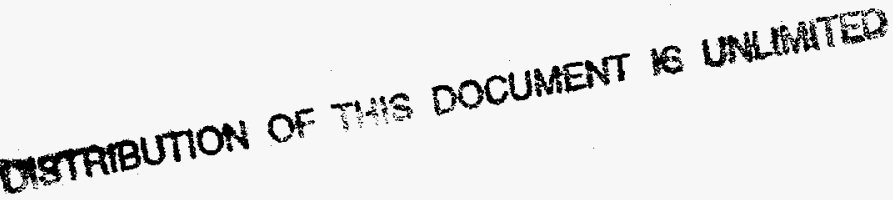


This report has been reproduced directly from the best available copy.

Available to DOE and DOE contractors from the Office of Scientific and Technical Information, P.O. Box 62, Oak Ridge, TN 37831; prices available from (615) 576-8401, FTS 626-8401.

Available to the public from the National Technical Information Service, U.S. Department of Commerce, 5285 Port Royal Rd., Springfield, VA 22161.

This report was prepared as an account of work sponsored by an agency of the United States Government. Neither the United States Government nor any agency thereof, nor any of their employees, makes any warranty, expressed or implied, or assumes any legal liability or responsibility for the accuracy, completeness, or usefulness of any information, apparatus, product, or process disclosed, or represents that its use would not infringe privately owned rights. Reference herein to any specific commercial product, process, or service by trade name, trademark, manufacturer, or otherwise, does not necessarily constitute or imply its endorsement, recommendation, or favoring by the United States Government or any agency thereof. The views and opinions of authors expressed herein do not necessarily state or reflect those of the United States Government or any agency thereof. 


\section{DISCLAIMER}

Portions of this document may be illegible electronic image products. Images are produced from the best available original document. 


\title{
ELECTRON CONCENTRATION AND PHASE STABILITY IN NbCr2-BASED LAVES PHASE ALLOYS
}

\author{
May 12, 1997 \\ Research sponsored by the U. S. Department of Energy, \\ Office of Fossil Energy \\ Advanced Research and Technology Development Materials Program
}

Report Prepared by

J. H. Zhu and P. K. Liaw

The University of Tennessee

Department of Materials Science and Engineering

Knoxville, TN 37996-2200

and

C. T. Liu

Metals and Ceramics Division

Oak Ridge National laboratory, Oak Ridge, TN 37831

under

Subcontract No. ORNL/Sub/93-SP173/02

for

OAK RIDGE NATIONAL LABORATORY

Oak Ridge, Tennessee 37831

Managed by

LOCKHEED MARTIN ENERGY RESEARCH CORP.

for the

U. S. DEPARTMENT OF ENERGY

under contract DE-AC05-96OR22464 
"Research sponsored by the U. S. Department of Energy, Fossil Energy Advanced Research and Technology Development Materials Program, DOE/FE AA 151010 0, Work Breakdown Structure Element UT-2(A)"

\begin{abstract}
Phase stability in $\mathrm{NbCr}_{2}$-based transition-metal Laves phases was studied, based on the data reported for binary $\mathrm{X}-\mathrm{Cr}, \mathrm{Nb}-\mathrm{X}$, and ternary $\mathrm{Nb}-\mathrm{Cr}-\mathrm{X}$ phase diagrams. It was shown that when the atomic size ratios are kept identical, the average electron concentration factor, $\mathrm{e} / \mathrm{a}$, is the dominating factor in controlling the phase stability of $\mathrm{NbCr}_{2}$-based transitionmetal Laves phases. The e/a ratios for different Laves polytypes were determined as follows: with e/a $<5.76$, the C15 structure is stabilized; at an e/a range of 5.88-7.53, the C14 structure is stabilized; with e/a $>7.65$, the C15 structure is stabilized again. A further increase in the electron concentration factor $(\mathrm{e} / \mathrm{a}>8)$ leads to the disordering of the alloy. The electron concentration effect on the phase stability of Mg-based Laves phases and transition-metal $A_{3} B$ intermetallic compounds is also reviewed and compared with the present observations in transition-metal Laves phases. In order to verify the $\mathrm{e} / \mathrm{a} / \mathrm{ph}$ ase stability relationship experimentally, additions of $\mathrm{Cu}($ with $\mathrm{e} / \mathrm{a}=11$ ) were selected to replace $\mathrm{Cr}$ in the $\mathrm{NbCr}_{2}$ Laves phase. Experimental results for the ternary $\mathrm{Nb}-\mathrm{Cr}-\mathrm{Cu}$ system are reported and discussed in terms of the correlation between the e/a ratio and phase stability in $\mathrm{NbCr}_{2}$-based Laves phases. A new phase was found, which has an average composition of $\mathrm{Nb}-47 \mathrm{Cr}-3 \mathrm{Cu}$. Within the solubility limit, the electron concentration and phase stability relationship is obeyed in the $\mathrm{Nb}-\mathrm{Cr}-\mathrm{Cu}$ system.
\end{abstract}




\section{INTRODUCTION}

Laves phases with $\mathrm{AB}_{2}$ compositions generally crystallize into one of the three topologically close-packed structures: cubic $\mathrm{C} 15-\mathrm{MgCu}_{2}$ structure, hexagonal C14 $\mathrm{MgZn}_{2}$ structure, and dihexagonal $\mathrm{C} 36-\mathrm{MgNi}_{2}$ structure. ${ }^{1}$ Although Laves phases are generally stabilized by the size-factor principles, that is, the atomic size ratio, $R_{A} / R_{B}$, is ideally 1.225 , with a range of 1.05-1.68 usually observed, the stability of each crystalline structure is also influenced by the electron concentration factor (e/a) ${ }^{2,3}$ In fact, the electron concentration factor becomes clearly important when the atomic size factors are favorable. The classic work by Laves and Witte ${ }^{2,3}$ showed that for several quasi-binary alloy systems involving $\mathrm{MgCu}_{2}$ and $\mathrm{MgZn}_{2}$, with increasing valence electron concentration, the three Laves types, $\mathrm{MgCu}_{2}, \mathrm{MgNi}_{2}$, and $\mathrm{MgZn}_{2}$, exist in that order. For transition-metal Laves phases, the average electron concentration and the $d$-band hole number were successfully used to correlate the crystal structure by Bardos, Gupta and Beck, ${ }^{4}$ and Watson and Bennet. $^{5,6}$

Transition-metal Laves phases are currently being considered for many practical applications, e.g., $(\mathrm{Hf}, \mathrm{Zr}) \mathrm{V}_{2}$ as superconducting material, $\mathrm{Zr}(\mathrm{Cr}, \mathrm{Fe})_{2}$ as hydrogen storage material, etc. More recently, $\mathrm{HfV}_{2}-, \mathrm{HfCr}_{2}$ - and $\mathrm{NbCr}_{2}$-based two-phase alloys ${ }^{7-13}$ are being developed for high-temperature structural uses, because of their retention of good mechanical properties at elevated temperatures. However, their low ductility and brittle fracture characteristics at ambient temperatures are the main concerns for structural applications of these materials.

One attractive way to improve the deformability of complex Laves phases is to control their crystalline structure in a way that stress-assisted phase transformation and/or mechanical twinning can be introduced during plastic deformation. ${ }^{14,15}$ It is thus important to know the factors governing the phase stability in transition-metal Laves alloys.

In this investigation, a number of binary and ternary phase diagrams were surveyed, and 
the phase stability criteria in the $\mathrm{NbCr}_{2}$-based Laves phase systems, binary $\mathrm{X}-\mathrm{Cr}$ and $\mathrm{Nb}-\mathrm{X}$ and ternary $\mathrm{Nb}-\mathrm{Cr}-\mathrm{X}$, were studied. The electron concentration factor (e/a) was identified as the key parameter in controlling the $\mathrm{C} 14 / \mathrm{C} 15$ phase stability in $\mathrm{NbCr}_{2}$-based transitionmetal Laves alloys, similar to the effect of electron concentration on the phase stability in Mg-based Laves phases and transition-metal $A_{3} B$ intermetallic alloys. Furthermore, the Laves-phase stability in the ternary $\mathrm{Nb}-\mathrm{Cr}-\mathrm{Cu}$ system was studied experimentally to verify the observed electron concentration/phase stability relationship. The results are discussed in terms of both solubility limit and electron concentration in the $\mathrm{Nb}-\mathrm{Cr}-\mathrm{Cu}$ system.

\section{LAVES PHASES IN BINARY X-Cr AND Nb-X SYSTEMS}

Since Laves phases are size compounds, we should choose the $\mathrm{X}$ elements in the $\mathrm{X}-\mathrm{Cr}$ systems with an atomic radius close to $\mathrm{Nb}$, and $\mathrm{X}$ elements in the $\mathrm{Nb}-\mathrm{X}$ systems with an atomic radius close to $\mathrm{Cr}$. In this scheme, we can easily separate the e/a factor from the atomic size factor in controlling the phase stability. According to this scheme, the $\mathrm{X}$ elements selected in the $\mathrm{X}-\mathrm{Cr}$ systems are $\mathrm{Ti}, \mathrm{Ta}$, and $\mathrm{Nb}$, and the $\mathrm{X}$ selected in the $\mathrm{Nb}-\mathrm{X}$ systems are $\mathrm{Cr}, \mathrm{Mn}, \mathrm{Fe}, \mathrm{Co}, \mathrm{Ni}$, and $\mathrm{Cu}$. The selection of atom size is based on the consideration of the Goldschmidt radius with a coordination number $(\mathrm{CN})$ of $12 .{ }^{16}$ With a minimum disturbance of the atomic size factor, the electron concentration ratio, e/a, should become a dominant factor in controlling the phase stability of the binary Laves phases. Here, the e/a ratio is defined as the average number of electrons per atom outside the closed shells of the component atoms. According to this definition, the e/a ratio of a transition element is the number of electrons ( $\mathrm{s}+\mathrm{d}$ electrons) outside its inert gas shell.

Table 1 lists the Goldschmidt radii $(\mathrm{CN}=12)$, and the e/a ratios of all the alloy components, together with the existing Laves phases observed in the binary $\mathrm{X}-\mathrm{Cr}$ and $\mathrm{Nb}$ $\mathrm{X}$ systems. It is interesting to note that $\mathrm{Ti}$ and $\mathrm{Ta}$ have atomic radii close to $\mathrm{Nb}$, and thus, they are postulated to substitute for $\mathrm{Nb}$ in the $\mathrm{NbCr}_{2}$ Laves phase. $\mathrm{Mn}, \mathrm{Fe}, \mathrm{Co}, \mathrm{Ni}$ and $\mathrm{Cu}$ have atom sizes close to $\mathrm{Cr}$ and occupy the $\mathrm{Cr}$ positions in the $\mathrm{NbCr}_{2}$ Laves phase. From 
the binary $\mathrm{X}-\mathrm{Cr}$ and $\mathrm{Nb}-\mathrm{X}$ phase diagrams, ${ }^{17}$ we can determine if the $\mathrm{XCr}_{2}$ or $\mathrm{NbX}_{2}$ Laves phase exists in the $\mathrm{X}-\mathrm{Cr}$ and $\mathrm{Nb}-\mathrm{X}$ systems, as indicated in Table 1. Also, the homogeneity ranges of $\mathrm{XCr}_{2}$ or $\mathrm{NbX}_{2}$ Laves phases can be determined from the binary phase diagrams. The homogeneity range (or mutual solubility) is defined here as the difference between the maximum and minimum atomic percents of $A$ in the $\mathrm{AB}_{2}$ phase. Corresponding to the homogeneity ranges, we can calculate the e/a ranges for the different binary Laves phases using the e/a ratios for various transition elements listed in Table 1 according to the following equation:

$$
(e / a)_{\text {Laves-phase }}=\sum_{i}\left[(e / a)_{i} \times(a t . \%)_{i}\right]
$$

where $i=i_{\text {th }}$ alloying element.

The binary Laves phase, $R_{A} / R_{B}$ ratio, homogeneity range (\% $A$ range), e/a range, and corresponding Laves phase structure are listed in Table 2. Since temperature is also a factor affecting the phase stability of Laves phases, polytypes may exist at different temperatures in some binary systems. To minimize or eliminate the temperature effect, the Laves structure investigated in the present study is the one stabilized at lower temperatures, if more than one Laves structure exist in the binary system. Also note that no Laves phases were observed in the binary $\mathrm{Nb}-\mathrm{Ni}$ and $\mathrm{Nb}-\mathrm{Cu}$ systems, and that the calculation of the e/a ratio was based on the imaginary " $\mathrm{NbNi}_{2}$ " and " $\mathrm{NbCu}_{2}$ " phases.

In Table 2, the $R_{A} / R_{B}$ ratios were maintained at approximately the same value for all of the Laves phases. The C15 structure was stabilized at low values of e/a $(\leq 5.70)$ in Table 2 . A change of the structure from $\mathrm{C} 15$ to $\mathrm{C} 14$ occurred when e/a was equal to or greater than 6.20. Interestingly, C15 was stabilized again when e/a was equal to or greater than 7.67 . As the e/a value further increases ( $\geq 8.34$ ), no ordered Laves phases exist. 


\section{LAVES PHASES IN TERNARY Nb-Cr-X SYSTEMS}

As postulated in the previous section, $\mathrm{Ti}$ and $\mathrm{Ta}$ occupy the $\mathrm{Nb}$ lattice sites in the $\mathrm{NbCr}_{2}$ Laves phase. From the ternary $\mathrm{Nb}-\mathrm{Cr}-\mathrm{Ta}$ and $\mathrm{Nb}-\mathrm{Cr}$ - $\mathrm{Ti}$ phase diagrams, ${ }^{18} \mathrm{Ti}$ or $\mathrm{Ta}$ can substitute for $\mathrm{Nb}$ from $0 \%$ to $100 \%$ without changing the $\mathrm{C} 15$ structure of $\mathrm{NbCr}_{2}$. This behavior further confirms our above postulation that $\mathrm{Ti}$ and $\mathrm{Ta}$ will mainly substitute for $\mathrm{Nb}$ in the $\mathrm{NbCr}_{2}$ Laves phase as the atomic radii of $\mathrm{Ta}, \mathrm{Ti}$ and $\mathrm{Nb}$ are essentially the same. For $\mathrm{Mn}, \mathrm{Fe}, \mathrm{Co}, \mathrm{Ni}$, and $\mathrm{Cu}$, they are postulated to substitute for $\mathrm{Cr}$ in the $\mathrm{NbCr}_{2}$ phase. There is no ternary $\mathrm{Nb}-\mathrm{Cr}-\mathrm{Mn}$ phase diagram reported so far, and the ternary $\mathrm{Nb}-\mathrm{Cr}-\mathrm{Cu}$ phase diagrams are incomplete, with the reported data mainly concentrated at the copperrich corner. On the other hand, the $\mathrm{Nb}-\mathrm{Cr}-\mathrm{Co}, \mathrm{Nb}-\mathrm{Cr}-\mathrm{Fe}$ and $\mathrm{Nb}-\mathrm{Cr}-\mathrm{Ni}$ phase diagrams

have been reported in the literature. ${ }^{18,19}$ From these phase diagrams, common trends were observed: $\mathrm{Fe}, \mathrm{Co}$ and $\mathrm{Ni}$ have some solubility in the $\mathrm{NbCr}_{2}$ phase without changing the C15 structure. However, above a certain critical amount of $\mathrm{Fe}$, $\mathrm{Co}$ or $\mathrm{Ni}$ added to the stoichiometric $\mathrm{NbCr}_{2}$ to substitute for $\mathrm{Cr}$, a phase modification from $\mathrm{C} 15$ to $\mathrm{C} 14$ was observed (Table 3). The C14 phase is stable over a wide range of Fe, Co or Ni content. For the $\mathrm{Nb}-\mathrm{Cr}-\mathrm{Co}$ system, a further increase in the Co content results in the reappearance of the C15 structure, ${ }^{19}$ as shown in Table 3.

The stability ranges of $\mathrm{C} 14$ and $\mathrm{C} 15$ phases in the ternary $\mathrm{Nb}-\mathrm{Cr}-\mathrm{X}$ systems at around $1000^{\circ} \mathrm{C}$ are summarized in Table 3 , together with the corresponding e/a values that were calculated using Equation 1. This temperature range was chosen due to the lack of pertinent ternary phase diagrams at lower temperatures. From Table 3, it should be noted that the solubility of $\mathrm{Fe}, \mathrm{Co}$, and $\mathrm{Ni}$ in $\mathrm{NbCr}_{2}$ with the $\mathrm{C} 15$ structure decreases in the order of $\mathrm{Fe}$, $\mathrm{Co}$, and $\mathrm{Ni}$. However, the e/a ratios corresponding to the change of the $\mathrm{C} 15$ to $\mathrm{C} 14$ structure are almost identical (i.e., 5.75, 5.76, and 5.77) for the different systems of $\mathrm{Nb}$ $\mathrm{Cr}-\mathrm{Fe}, \mathrm{Nb}-\mathrm{Cr}-\mathrm{Co}$ and $\mathrm{Nb}-\mathrm{Cr}-\mathrm{Ni}$, respectively. This trend implies that the average electron concentration may play a key role in determining the $\mathrm{C} 15 / \mathrm{C} 14$ phase stability. The average maximum e/a for the $\mathrm{C} 15$ structure is $\mathbf{5 . 7 6}$ and the average minimum e/a ratio to stabilize the $\mathrm{C} 14$ structure is about 5.88. A transition from $\mathrm{C} 14$ to $\mathrm{C} 15$ was observed in the $\mathrm{Nb}-\mathrm{Cr}$ - 
Co system when e/a was equal to or greater than 7.65 . Note that the transition from $\mathrm{C} 14$ to C15 was also found in the binary Laves phases, as shown in Table 2.

\section{EFFECT OF e/a ON LAVES-PHASE STABILITY}

Laves phases are compounds of the general formula $\mathrm{AB}_{2}$, with three crystal types, $\mathrm{C} 15$, C36, and C14, generally observed. There is a marked similarity among the three structures. These consist of double layers of hexagonal arrays of A atoms surrounded by tetrahedra of the B elements. One stacking layer consists of 4 sub-layers, and thus, they are called quadruple layers. The cubic C15 structure consists of such layers stacked ABCABC, while the $\mathrm{C} 14$ consists of such layers stacked $\mathrm{ABABABAB}$. $\mathrm{C} 36$ may be regarded as a transitional phase between the $\mathrm{C} 15$ and $\mathrm{C} 14$ structures with a stacking of these layers $\mathrm{ABACABAC}$. Laves phases are size compounds, and therefore, the size difference between A and B atoms is predominant in stabilizing the Laves phase. Since we purposely chose some alloying elements with roughly the same atomic sizes with either $\mathrm{Cr}$ or $\mathrm{Nb}$ (see Tables 1 and 2), the atomic size difference between $A$ and $B$ is similar in the $A B_{2}$ Laves phases investigated. This approach simplifies our analysis, since we can separate the other factors from the size factor in stabilizing different Laves phase structures. Also, we only chose transition metals to form Laves phases, which made it ideal to study the e/a effect on the Laves-phase stability. In transition metals, filling the d-band is important for the phase stability.

In Laves and Witte's studies, ${ }^{2,3}$ ternary $\mathrm{Mg}$-based systems were selected, and a valence electron concentration rule was found to control the occurrence of various Laves structures, with C15 stabilized at low e/a values, C14 stabilized at high e/a values, and C36 in between, see Fig. 1. The correlation is reasonably good; however, both non-transition and transition metals were involved in forming some Laves phases in their study, making it difficult to analyze the valence electron concentrations in the alloys. This difficulty results from the fact that for a transition element, the valence electron number is not a constant value, but varies in different systems. This behavior may contribute to the scattering in the 
critical e/a values corresponding to the phase transitions for the different ternary systems, as shown in Fig. 1, e.g., there is an overlapping of the C14 and C36 structures in the valence electron concentration ranges between 1.8 and 2.0.

In the present evaluation, all the elements chosen to form Laves phases were transition metals. Instead of using the valence electron concentration, the average electron concentration was chosen for correlation purposes. This concept of average electron concentration has been successfully used to obtain a correlation between the e/a value and the phase stability in some transition metal alloy systems. ${ }^{4,5,20-24}$ If we combine the data in Tables 2 and 3 for both binary and ternary alloy systems, we can clearly demonstrate the e/a effect on the phase stability (C14/C15) in $\mathrm{NbCr}_{2}$-based Laves alloys (see Fig. 2).

At e/a values lower than 5.76 , the $\mathrm{C} 15$ structure was stabilized for both binary and ternary Laves alloys (Fig. 2). By increasing e/a to 5.88, the C14 structure was stabilized. Over the e/a range of 5.88-7.53, the $\mathrm{C} 14$ structure is more stable than the $\mathrm{C} 15$ structure. This trend is similar to that observed in the Mg-based Laves phases, ${ }^{2,3}$ where the $\mathrm{C} 15 \rightarrow \mathrm{C} 36 \rightarrow \mathrm{C} 14$ phase modification was observed with an increasing e/a value (Fig. 1). However, for the Mg-based Laves phases, this should be considered as a tendency, as it is impossible to classify the compounds in terms of their e/a ratios, as discussed before.

In ternary $\mathrm{NbCr}_{2}$-based Laves phases, the e/a ratio for the $\mathrm{C} 15 / \mathrm{C} 14$ phase boundaries is very precise, with $\mathrm{C} 15$ existing at $\mathrm{e} / \mathrm{a} \leq 5.76$, and $\mathrm{C} 14$ occurring at e/a $\geq 5.88$ (Fig. 2). This may be associated with the fact, as mentioned previously, that all the components of the ternary $\mathrm{NbCr}_{2}$-based Laves phases are transition metals. The region between the two single phase regions should be a two phase mixture of $\mathrm{C} 14$ and $\mathrm{C} 15$ from thermodynamic considerations. However, in reality, it is possible to obtain different intermediate structures, due to the metastable transformation of the one to the other and/or the low chemical free energies of some intermediate structures. For example, the C36 phase exists in some Mg-based Laves alloys, as shown in Fig.1. 
Moreover, Komura and his coworkers have shown that additional Laves-type structures exist in at least some of these quasi-binary Mg-based systems. ${ }^{25-27}$ The hexagonality of the stacking arrangement decreases, and then increases with increasing valence electron concentration, i.e., as the valence electron concentration increases, the percentage of hexagonality observed changes in the following sequence of $50 \rightarrow 33 \rightarrow 0 \rightarrow 50 \rightarrow 57 \rightarrow 60 \rightarrow 62 \rightarrow 66 \rightarrow 71 \rightarrow 75 \rightarrow 100$.

However, no existence of $\mathrm{C} 36$ and other intermediate structures were indicated in the reported phase diagrams of binary and ternary $\mathrm{NbCr}_{2}$-based systems between the $\mathrm{C} 14$ and C15 phase fields. This is probably due to the fact that no detailed work on crystal structures was undertaken to determine the various intermediate structures in this region. Thus, it is postulated that at least in some of the $\mathrm{NbCr}_{2}$-based Laves-phase systems, $\mathrm{C} 36$ and other intermediate structures may exist in the e/a regime of 5.76-5.88, probably around 5.7-5.9 due to the variability in the literature data. In fact, a C36 phase was detected in a recent study of the transition-metal Nb-Cr-Fe system. ${ }^{15}$ Even though it is difficult to calculate the exact e/a value for the C36 Laves phase, since that system is basically a dual-phase alloy with a $\mathrm{Nb}$ solid solution and a Laves phase, it does indicate that it is possible to stabilize at least the $\mathrm{C} 36$ structure at certain e/a ratios.

Over the e/a range considered, the atomic size difference has no effect on the e/a correlation with the phase stability in both binary and ternary $\mathrm{NbCr}_{2}$-based systems. Actually, the solubility of $\mathrm{Fe}, \mathrm{Co}$ and $\mathrm{Ni}$ in $\mathrm{NbCr}_{2}$ has different values, yet the same critical e/a value is yielded, with respect to the change of the crystal structure from $\mathrm{C} 15$ to $\mathrm{C} 14$ (Fig. 2). These observations may result from the fact that the atomic size difference $\left(R_{A} / R_{B}\right)$ is kept similar in our investigation. However, the atomic size difference may affect the homogeneity range of the $\mathrm{NbCr}_{2}$-based Laves phase, as shown in Fig. 3. No good correlation between the $R_{A} / R_{B}$ ratio with the homogeneity range can be inferred from Fig. 3. Note that all the binary Laves phases considered show a certain amount of homogeneity range, a result consistent with the geometry analysis of solubility ranges in Laves phases 
performed by Thoma and Perepezko. ${ }^{28}$

The effect of the average electron concentration on phase stability has been shown in some transition-metal $\mathrm{A}_{3} \mathrm{~B}$ intermetallic compound systems, usually with a very good correlation obtained. $^{20-22}$ For example, Liu found that the stacking character of the $(\mathrm{Fe}, \mathrm{Co}, \mathrm{Ni})_{3} \mathrm{~V}$ ordered alloys can be altered systematically by controlling the e/a ratio of the alloys ${ }^{20}$ (see Fig. 4). Here, the basic $A_{3} B$ one-layer structure is the (111) close-packed plane, which is different from the case for Laves phases, where a quadruple layer forms a close packed plane. Different ordered structures can be obtained depending on their stacking sequence. Similar to our observation in Laves phases, as e/a increases, the stacking character changes from purely cubic, through a mixture of cubic and hexagonal, to purely hexagonal. However, the critical e/a ratios for stabilizing the ordered face-centered cubic (f.c.c.) structure ( $\leq 7.89)$ and ordered hexagonal close-packed (h.c.p.) structure $(\geq 8.54)$ in $A_{3} B$ compounds are different from those for stabilizing the cubic C15 structure $(\leq 5.76)$ and hexagonal $\mathrm{C} 14$ structure $(\geq 5.88)$ in the $\mathrm{NbCr}_{2}$-based transition-metal Laves phases. Also, similar to Mg-based Laves phase alloys, different ordered mixtures of cubic and hexagonal layers were obtained between the cubic and hexagonal structures for the $A_{3} B$ ordered alloys, i.e., $\mathrm{Co}_{3} \mathrm{~V}$ with $\mathrm{e} / \mathrm{a}=8$ shows 33.3 percent hexagonality and $(\mathrm{Co}, \mathrm{Ni})_{3} \mathrm{~V}$ with $\mathrm{e} / \mathrm{a}=$ 8.43 shows 66.7 percent hexagonality. All the results indicate that the average electron concentration factor has a determinate effect on the phase stability of transition-metal intermetallic compounds. The reason leading to such a correlation is not clear now; however, the phase transition in transition metals is known to be related to the filling of an appropriate Brillouin zone $\mathrm{e}^{20,22}$ and can be predicted from the ground state phase stability map. $^{29}$

From Fig. 2 and Table 3, we can also see that for the $\mathrm{Nb}-\mathrm{Cr}-\mathrm{Co}$ system, when the e/a ratio increases further to 7.65 , the C15 structure was stabilized again over the C14 structure. Similarly in the binary systems, there is a $\mathrm{C} 14 \rightarrow \mathrm{C} 15$ transition when e/a is greater than 7.65 (Fig. 2 and Table 2). This structure modification of C14 to C15 with a further increase in the e/a ratio has been observed in a number of transition-metal Laves phases. ${ }^{30}$ 
It is a general trend, rather than an exception. In the ternary $\mathrm{Nb}-\mathrm{Cr}-\mathrm{Fe}$ system, we cannot observe such a $\mathrm{C} 14$ to $\mathrm{C} 15$ transition, since we are unable to obtain an e/a ratio higher than 7.6 in this system (Fig. 2 and Table 3). No $\mathrm{NbNi}_{2}$ (with e/a = 8.34) and $\mathrm{NbCu}_{2}$ (with e/a =9) Laves phases exist in binary $\mathrm{Nb}-\mathrm{Ni}$ and $\mathrm{Nb}-\mathrm{Cu}$ systems (Table 2), a fact consistent with the observation by Bardos et al. ${ }^{4}$ that at e/a $>8$, a disordered structure is stabilized over the Laves phase in transition-metal systems. Also in agreement with Bardos et al., the maximum e/a ratio for the Laves phases in the $\mathrm{Nb}-\mathrm{Cr}-\mathrm{Ni}$ system is around 8. However, no $\mathrm{C} 14 \rightarrow \mathrm{C} 15$ transition in the $\mathrm{Nb}-\mathrm{Cr}-\mathrm{Ni}$ system was reported at e/a ratios $>$ 7.65 , possibly due to the fact that many ternary phase diagrams containing Laves phases are inaccurate with regard to the identification of $\mathrm{C} 14 / \mathrm{C} 36 / \mathrm{C} 15$ structures. Note that as discussed before, it is postulated that C36 and other intermediate structures may exist between $\mathrm{C} 14$ and $\mathrm{C} 15$ structures at $7.65>\mathrm{e} / \mathrm{a}>7.53$.

If the electron concentration e/a correlation with the phase stability (Fig. 2) is a rule operating in the $\mathrm{NbCr}_{2}$-based transition-metal alloy systems, it will be possible to change from $\mathrm{C} 15$ to $\mathrm{C} 14$ and from $\mathrm{C} 14$ to $\mathrm{C} 15$ again by adding $\mathrm{Cu}(\mathrm{e} / \mathrm{a}=11)$ into $\mathrm{NbCr}_{2}$ to substitute for $\mathrm{Cr}$, i.e., by varying the e/a ratio in the alloy. So far, no data are available for the ternary $\mathrm{Nb}-\mathrm{Cr}-\mathrm{Cu}$ system. Thus, the $\mathrm{Nb}-\mathrm{Cr}-\mathrm{Cu}$ system was chosen in this investigation, and the results in this system are reported in the next section.

\section{EXPERIMENTAL STUDY OF THE e/a CORRELATION}

From Table 1, $\mathrm{Cu}$ has eleven outshell electrons (the highest e/a). Thus, the addition of $\mathrm{Cu}$ to substitute for $\mathrm{Cr}(\mathrm{e} / \mathrm{a}=6)$ in $\mathrm{NbCr}_{2}$ is very effective in increasing the average electron concentration. By a systematic replacement of $\mathrm{Cr}$ with $\mathrm{Cu}$, it is possible to see a whole spectrum (e.g., C15 $\rightarrow \mathrm{C} 14 \rightarrow \mathrm{C} 15)$ of changes in the crystal structure of the Laves-phase based $\mathrm{Nb}(\mathrm{Cr}, \mathrm{Cu})_{2}$ compositions. A series of pseudo-binary $\mathrm{Nb}(\mathrm{Cr}, \mathrm{Cu})_{2}$ alloys with 1,3 , 5,10 at $\% \mathrm{Cu}$ were produced by replacing $\mathrm{Cr}$ with $\mathrm{Cu}$, while keeping the percentage of $\mathrm{Nb}$ constant. The nominal chemical compositions in the atomic percentage of the alloys studied in this work are $\mathrm{Nb}-65.6 \mathrm{Cr}-1 \mathrm{Cu}, \mathrm{Nb}-63.6 \mathrm{Cr}-3 \mathrm{Cu}, \mathrm{Nb}-61.6 \mathrm{Cr}-5 \mathrm{Cu}$, and $\mathrm{Nb}-56.6 \mathrm{Cr}-$ 
$10 \mathrm{Cu}$, which correspond to average electron concentrations of $5.71,5.81,5.91$ and 6.16 , respectively. These four alloys are in the $\mathrm{C} 15$ region, the $\mathrm{C} 15 / \mathrm{C} 14$ transition region, and the C14 region, respectively, according to the prediction of Fig. 2.

All the alloys of about 50 grams were prepared by arc-melting techniques using starting materials of $99.8 \% \mathrm{Nb}, 99.99 \% \mathrm{Cr}$, and $99.99 \% \mathrm{Cu}$. An excess amount (typically $1 \%$ ) of $\mathrm{Cr}$ was added to compensate for the evaporation loss of $\mathrm{Cr}$ during melting. Arc-melting was carried out in a chamber which was evacuated by a mechanical pump and flushed with ultra-high purity (UHP) argon gas four or five times, and finally backfilled with UHP argon gas. A $\mathrm{Zr}$ sample was melted prior to melting the alloy charge each time in order to getter the oxygen in the chamber. The arc-melting was done using a thoriated tungsten electrode on a water-cooled copper hearth. Each ingot was inverted and remelted at least 7 times to ensure macroscopic compositional homogeneity. The material was heat-treated in vacuum at $1400^{\circ} \mathrm{C}$ for 120 hours, then slowly cooled in the furnace.

An electron microprobe equipped with wavelength-dispersive spectrometry (WDS) was used to identify the microstructure and the chemical compositions of various phases in the heat-treated specimens. X-ray diffraction measurements were made using a Scintag $\mathrm{XD} 2000$ diffractometer with the $\mathrm{Cu} \mathrm{K}_{\alpha}(\lambda=0.15406 \mathrm{~nm})$ radiation.

$\mathrm{X}$-ray diffraction results show that the Laves phase after the addition of up to 10 at. $\% \mathrm{Cu}$ maintains its original C15 structure, i.e., no phase transition is observed for all the alloys investigated. As an example, Fig. 5 shows the indexed $\mathrm{C} 15$ diffraction pattern for the $\mathrm{Nb}$ $61.6 \mathrm{Cr}-5 \mathrm{Cu}$ alloy. This seems to contradict our e/a correlation with phase stability, as the addition of 5 at $\% \mathrm{Cu}$ should stabilize the $\mathrm{C} 14$ structure according to Fig. 2. Optical microscopy shows that more than one phase are present in the 5 at $\% \mathrm{Cu}$ alloy, see Fig. 6(a). Using the electron microprobe, it was found that four phases coexist in this alloy, see Fig. 6(b).

Table 4 summarizes the results of the electron microprobe analyses. Here, the matrix is the 
Laves phase with an average composition of $\mathrm{Nb}=33.9, \mathrm{Cr}=64.8$ and $\mathrm{Cu}=1.3$. From this composition, it can be seen that $\mathrm{Cu}$ indeed substitutes for $\mathrm{Cr}$ in the $\mathrm{NbCr}_{2}$ phase. The bright phase has a formula of roughly $\mathrm{AB}$ assuming again that $\mathrm{Cu}$ substitutes for $\mathrm{Cr}$ in the lattice. This phase is possibly a $\sigma$ phase, which does not exist in the $\mathrm{Cr}-\mathrm{Nb}$ binary system. It is interesting to note that the addition of 3 at $\% \mathrm{Cu}$ stabilizes this bright phase. This new phase has not been reported before and deserves further investigations. The dark phase and the gray phase are $\mathrm{Cu}$ and $\mathrm{Nb}$ solid solutions, respectively. The solubility of $\mathrm{Nb}$ and $\mathrm{Cr}$ in $\mathrm{Cu}$ is only 0.1 and $2.55 \%$, respectively. The gray phase is a $\mathrm{Nb}$ solid solution with $0.44 \% \mathrm{Cu}$ and $4.19 \% \mathrm{Cr}$.

The low solubility of $\mathrm{Cu}$ in the $\mathrm{NbCr}_{2}$ phase, i.e., 1.3 at. \%, is a rather surprising finding. The average electron concentration of the Laves phase in the $\mathrm{Nb}-61.6 \mathrm{Cr}-5 \mathrm{Cu}$ alloy can be calculated to be 5.73. Since an average electron concentration of 5.73 is still in the C15 range, as shown in Fig. 2, no phase transition will be expected. Thus, the experimental results are, in fact, consistent with our e/a correlation prediction, i.e., when $\mathrm{e} / \mathrm{a}<5.76$, the $\mathrm{C} 15$ structure is stabilized. The question arising here is why the solubility of $\mathrm{Cu}$ in the $\mathrm{NbCr}_{2}$ phase is so low, since its atomic radius is favorable for it to substitute for $\mathrm{Cr}$ (Table 1). According to Hume-Ruthery's rules on the solubility of a solid solution, three parameters, namely, e/a, atomic radius, and electronegativity, are dominating factors in determining the solubility limit. Since both the e/a and electronegativity differences between $\mathrm{Cr}$ and $\mathrm{X}$ in the binary $\mathrm{NbX}_{2}$ system are the largest for $\mathrm{Cu}$, the low solubility of $\mathrm{Cu}$ in the $\mathrm{NbCr}_{2}$ phase is believed to be a combination of unfavorable e/a and electronegativity for $\mathrm{Cu}$ to be dissolved in $\mathrm{Cr}$.

The $\mathrm{Nb}-61.6 \mathrm{Cr}-5 \mathrm{Cu}$ alloy was also heat-treated in the following way to achieve an equilibrium condition at $1000^{\circ} \mathrm{C}: 1400^{\circ} \mathrm{C}$ for 120 hours, $1000^{\circ} \mathrm{C}$ for 120 hours, followed by water quenching. X-ray diffraction results show the diffraction pattern of $\mathrm{C} 15$, while the optical microstructure of the alloy is similar to that after furnace cooling, see Fig. 6(a). These results also indicate that $\mathrm{C} 15$ is the stable structure in this $\mathrm{Nb}-\mathrm{Cr}-\mathrm{Cu}$ alloy at $1000^{\circ} \mathrm{C}$. Moreover, the above results indicate that within the solubility limit, the crystal structure of 
the $\mathrm{Nb}-\mathrm{Cr}-\mathrm{Cu}$ alloy obeys the e/a and phase stability relationship presented in Fig. 2.

\section{CONCLUSIONS}

Binary $\mathrm{X}-\mathrm{Cr}$ and $\mathrm{Nb}-\mathrm{X}$, and ternary $\mathrm{Nb}-\mathrm{Cr}-\mathrm{X}$ phase diagrams were surveyed, and some interesting phase stability features were identified in these transition-metal systems. The average electron concentration factor (e/a) has been shown to be a dominant factor in controlling the phase stability of $\mathrm{NbCr}_{2}$-based transition-metal Laves alloys. With e/a $\leq$ 5.76, the C15 structure is stabilized; at an e/a range of $5.88-7.53$, the C14 structure is stabilized; with e/a $\geq 7.65$, the $\mathrm{C} 15$ structure is stabilized again. A further increase in electron concentration ( $\mathrm{e} / \mathrm{a}>8$ ) leads to the disordering of the alloy. It is postulated that at $5.88>\mathrm{e} / \mathrm{a}>5.76$ and $7.65>\mathrm{e} / \mathrm{a}>7.53$, the $\mathrm{C} 36$ and other intermediate structures may be stabilized. Such an e/a correlation is found to be analogous to that in $\mathrm{A}_{3} \mathrm{~B}$ transition-metal intermetallic compounds and Mg-based Laves phases. An experimental investigation of ternary $\mathrm{Nb}-\mathrm{Cr}-\mathrm{Cu}$ systems indicates that the solubility of $\mathrm{Cu}$ in the $\mathrm{NbCr}_{2}$ phase is as low as 1.3 at. \%. Other phases, such as $\sigma$ phase, a $\mathrm{Cu}$-rich, and $\mathrm{Nb}$-rich phase, can be stabilized in the $\mathrm{Nb}(\mathrm{Cr}, \mathrm{Cu})_{2}$ composition with 5 at. \% $\mathrm{Cu}$. However, within the solubility limit, the electron concentration/phase stability correlation is obeyed in this ternary system.

\section{ACKNOWLEDGMENTS}

We would like to thank Nancy Cole and Rod Judkins of the Oak Ridge National Laboratory for programmatic support, and Joe Wright and Cecil Carmichael for their technical assistance. The research was sponsored by the Fossil Energy AR \& TD Materials Program, U.S. Department of Energy, under subcontract $11 \mathrm{X}-\mathrm{SP} 173 \mathrm{~V}$ to the University of Tennessee with Lockheed Martin Energy Research Corp.

\section{REFERENCES}

1. T.B. Massalski: in Physical Metallurgy Part 1, R. W. Cahn \& P. Hassen, eds., North- 
Holland Physics Publishing, NY, 1983, p. 190.

2. F. Laves \& H. Witte, Metallwirschaft, 1935, vol. 14, p. 645.

3. F. Laves \& H. Witte, Metallwirschaft, 1936, vol. 15, p. 840.

4. D.I. Bardos, K.P. Gupta, \& P.A. Beck, Trans. Met. Soc. AIME, 1961; vol. 221, p. 1087.

5. R.E. Watson and L.H. Bennett, Acta Metall., 1984, vol. 32, p. 477.

6. R.E. Watson and L.H. Bennett, Acta Metall, 1984, vol. 32, p. 491.

7. F. Chu and D.P. Pope: in High-Temperature Ordered Intermetallic Alloys V, 1993, MRS. Symp. Proc. 288, p. 561.

8. K. S. Kumar and D.B. Miracle, Intermetallics, 1994, vol. 2, p. 257.

9. M. Takeyama and C.T. Liu, Mater. Sci. \& Eng. A, 1991, vol. 132, p. 61.

10. J.A. Cook, P.K. Liaw, and C.T. Liu: in Fatigue and Fracture of Ordered Intermetallics, W. O. Soboyejo, T. S. Srivatsan \& R. O. Ritchie, eds., TMS, Warrendale, PA, 1995, p. 155.

11. J.A. Cook, P.K. Liaw, C.T. Liu, and S.B. Bhaduri: in the Johannes Weertman Symposium, R. J. Arsenault et al., eds., TMS, Warrendale, PA, 1996, p. 47.

12. K.S. Chan and D.L. Davidson, JOM, Sept. 1996, 62.

13. D.J. Thoma and J.H. Perepezko, Mater. Sci. \& Eng. A, 1992, vol. 156, p. 97.

14. Y. Liu, J.D. Livingston, and S.M. Allen, Metall. Tran. A, 1992, vol. 23, p. 3303.

15. M. Grujicic, S. Tangrila, O.B. Cavin, W.D. Porter, and C.R. Hubbard, Mater. Sci. \& Eng. A, 1993, vol. 160, p. 37.

16. F. Laves: in Theory of Alloy Phases, American Society for Metals, Metals Park, $\mathrm{OH}$, 1956, p. 124.

17. T.B. Massalski, J.L. Murray, L.H. Bennet, and H. Baker, Binary Alloy Phase Diagram, American Society for Metals, Metals Park, OH, 1986.

18. P. Villars, A. Prince, and H. Okamoto, Handbook of Ternary Phase Diagrams, ASM International, 1995.

19. N.I. Kaloev, E.M. Sokolovskaya, A.Kh. Abramyan, and R.V. Kalagova, Soviet Non-Ferrous Metals Research , 1986, vol. 14, p. 503.

20. C.T. Liu, Inter. Met. Rev., 1984, vol. 29, p. 168. 
21. A.K. Sinha, Tran. Met. Soc. AIME, 1969, vol. 245, p. 911.

22. A.K. Sinha, Progr. in Mater. Sci. Part 2, 1972, vol. 15, p. 79.

23. D.I. Bardos, R.K. Malik, F.X. Spiegel, P.A. Beck, Trans. Met. Soc. AIME, 1966, vol. 236 , p. 40.

24. V.V. Savin, Phys. Met. Metall., 1989, vol.68, p. 140.

25. Y. Komura, Acta Cryst., 1962, vol. 15, p. 770.

26. Y. Komura, , E. Kotera, and M. Mitarai, Acta Cryst. A, 1969, vol. 25, p. S96.

27. Y. Komura and Y. Kitano, Y., Acta Cryst. B, 1977, vol. 33, p. 2496.

28. D.J. Thoma and J.H. Perepezko, J. of Alloys and Compounds, 1995, vol. 224, p. 330.

29. Shiyou Pei and T.B. Massalski, Acta Metall. Mater., 1995, vol. 43, p. 2385.

30. K. Kuo, Acta Metall., 1953, vol. 1, p. 720. 
Table 1. Atomic Size, Electron Concentration Factor (e/a) of Alloying Element, and Existing Binary Laves Phase

\begin{tabular}{cccc}
\hline Element & Goldschmidt Radius $(\AA) *$ & $\mathrm{e}^{+}$ & $\mathrm{XCr}_{2} / \mathrm{NbX}_{2}$ \\
\hline $\mathrm{Nb}$ & 1.47 & 5 & $\mathrm{NbCr}_{2}$ \\
\hline $\mathrm{Ti}$ & 1.45 & 4 & $\mathrm{TiCr}_{2}$ \\
\hline $\mathrm{Ta}$ & 1.46 & 5 & $\mathrm{TaCr}_{2}$ \\
\hline $\mathrm{Cr}$ & 1.28 & 6 & $\mathrm{NbCr}_{2}$ \\
\hline $\mathrm{Mn}$ & 1.31 & 7 & $\mathrm{NbMn}_{2}$ \\
\hline $\mathrm{Fe}$ & 1.27 & 8 & $\mathrm{NbFe}_{2}$ \\
\hline $\mathrm{Co}$ & 1.26 & 9 & $\mathrm{NbCO}_{2}$ \\
\hline $\mathrm{Ni}$ & 1.24 & 10 & None \\
\hline $\mathrm{Cu}$ & 1.28 & 11 & None
\end{tabular}

* Data from Reference 16.

+ The unit of e/a is the number of electrons per atom in this paper.

Table 2. Atomic Size Ratio $\left(\mathrm{R}_{\mathrm{A}} / \mathrm{R}_{\mathrm{B}}\right)$, Homogeneity Range (\%A Range), Corresponding e/a Range and Laves Phase Structure in Binary $\mathrm{XCr}_{2}$ and $\mathrm{NbX}_{2}$ Alloy Systems

\begin{tabular}{ccccc}
\hline Laves Phase & $\mathrm{R}_{\mathrm{A}} / \mathrm{R}_{\mathrm{B}}$ & \%ARange & e/a Range & Structure \\
\hline $\mathrm{TiCr}_{2}$ & 1.133 & $35-37$ & $5.26-5.30$ & $\mathrm{C} 15$ \\
$\mathrm{TaCr}_{2}$ & 1.141 & $33-36$ & $5.64-5.67$ & $\mathrm{C} 15$ \\
$\mathrm{NbCr}_{2}$ & 1.148 & $30-39$ & $5.61-5.70$ & $\mathrm{C} 15$ \\
$\mathrm{NbMn}_{2}$ & 1.122 & $25.5-40$ & $6.20-6.49$ & $\mathrm{C} 14$ \\
$\mathrm{NbFe}_{2}$ & 1.157 & $27-38$ & $6.86-7.19$ & $\mathrm{C} 14$ \\
$\mathrm{NbCO}_{2}$ & 1.167 & $27-33.3$ & $7.67-7.92$ & $\mathrm{C} 15$ \\
" $\mathrm{NbNi}_{2}$ ", & 1.185 & 33.3 & 8.34 & None \\
"NbCu " & 1.148 & 33.3 & 9.00 & None \\
\hline
\end{tabular}


Table 3. Homogeneity Range $(\% \mathrm{X})$ and Corresponding e/a Range of C15/C14 Structures in Ternary $\mathrm{Nb}-\mathrm{Cr}-\mathrm{X}$ Systems

\begin{tabular}{ccccccc}
\hline & \multicolumn{2}{c}{$\mathrm{C} 15$} & \multicolumn{2}{c}{$\mathrm{C14}$} & \multicolumn{2}{c}{$\mathrm{C15}$} \\
\cline { 2 - 7 } $\mathrm{X}$ & $\% \mathrm{X}$ & $\mathrm{e} / \mathrm{a}$ & $\% \mathrm{X}$ & $\mathrm{e} / \mathrm{a}$ & $\% \mathrm{X}$ & $\mathrm{e} / \mathrm{a}$ \\
\hline $\mathrm{Ti}$ & $0-33.3$ & $5.33-5.67$ & -- & -- & -- & - \\
$\mathrm{Ta}$ & $0-33.3$ & 5.67 & -- & -- & -- & -- \\
$\mathrm{Fe}$ & $0-4$ & $5.67-5.75$ & $9-66.7$ & $5.85-6.69$ & -- & - \\
$\mathrm{Co}$ & $0-3$ & $5.67-5.76$ & $8-62$ & $5.91-7.53$ & $66-68$ & $7.65-7.72$ \\
$\mathrm{Ni}$ & $0-2.5$ & $5.67-5.77$ & $5-52$ & $5.87-8.05$ & -- & -- \\
\hline
\end{tabular}

Table 4 Chemical Compositions of Different Phases in $\mathrm{Nb}(\mathrm{Cr}, \mathrm{Cu})_{2}$ with 5 at. \% $\mathrm{Cu}$ as Determined by Electron Microprobe

\begin{tabular}{|c|c|c|c|c|}
\hline Phases & Point & Nb (at. \%) & Cr (at. \%) & Cu (at. \%) \\
\hline \multirow{5}{*}{ Matrix } & 1 & 34.11 & 64.57 & 1.32 \\
& 2 & 34.17 & 64.70 & 1.14 \\
& 3 & 33.94 & 64.94 & 1.12 \\
& 4 & 33.48 & 65.11 & 1.41 \\
& 5 & 34.09 & 64.55 & 1.37 \\
& 6 & 33.73 & 64.91 & 1.37 \\
\cline { 2 - 5 } & Average & 33.92 & 64.80 & 1.29 \\
\hline \multirow{5}{*}{ Bright Phase } & 1 & 50.46 & 46.24 & 3.30 \\
& 2 & 49.81 & 46.99 & 2.77 \\
& 3 & 49.97 & 46.98 & 3.05 \\
& 4 & 51.45 & 45.70 & 2.86 \\
\cline { 2 - 5 } & Average & 49.78 & 47.11 & 3.11 \\
\hline \multirow{5}{*}{ Dark phase } & 1 & 0.29 & 46.60 & 3.02 \\
& 2 & 0.05 & 2.87 & 96.87 \\
& 3 & 0 & 2.28 & 97.67 \\
\cline { 2 - 5 } & Average & 0.10 & 2.49 & 97.51 \\
\hline Gray Phase & 1 & 95.37 & 4.19 & 07.35 \\
\hline
\end{tabular}




\section{Figure Caption}

Fig. 1 Effect of valence electron concentration on phase stability for several ternary Mgbased Alloys [reproduced after Ref. 1]

Fig. 2 Effect of average electron concentration (e/a) on phase stability in binary and ternary $\mathrm{NbCr}_{2}$-based systems

Fig. 3 Effect of $R_{A} / R_{B}$ ratio on the solubility range of binary Laves phases

Fig. 4 Effect of average electron concentration (e/a) on ordered structures in pseudo-binary $\mathrm{Ni}_{3} \mathrm{~V}-\mathrm{Co}_{3} \mathrm{~V}$ and $\mathrm{CO}_{3} \mathrm{~V}-\mathrm{Fe}_{3} \mathrm{~V}$ systems [Reproduced after Ref. 20]

Fig. $5 \mathrm{X}$-ray diffraction pattern of the $\mathrm{Nb}-61.6 \mathrm{Cr}-5 \mathrm{Cu}$ alloy, indexed as the $\mathrm{C} 15$ structure

Fig. 6 Microstructure of the $\mathrm{Nb}-61.6 \mathrm{Cr}-5 \mathrm{Cu}$ alloy, as-polished condition, (a) optical micrograph with polarized-light; (b) back-scattering electron micrograph. Phases 1, 2, 3 and 4 are Laves phase, $\sigma$-phase, $\mathrm{Cu}$ and $\mathrm{Nb}$ solid solutions, respectively. 


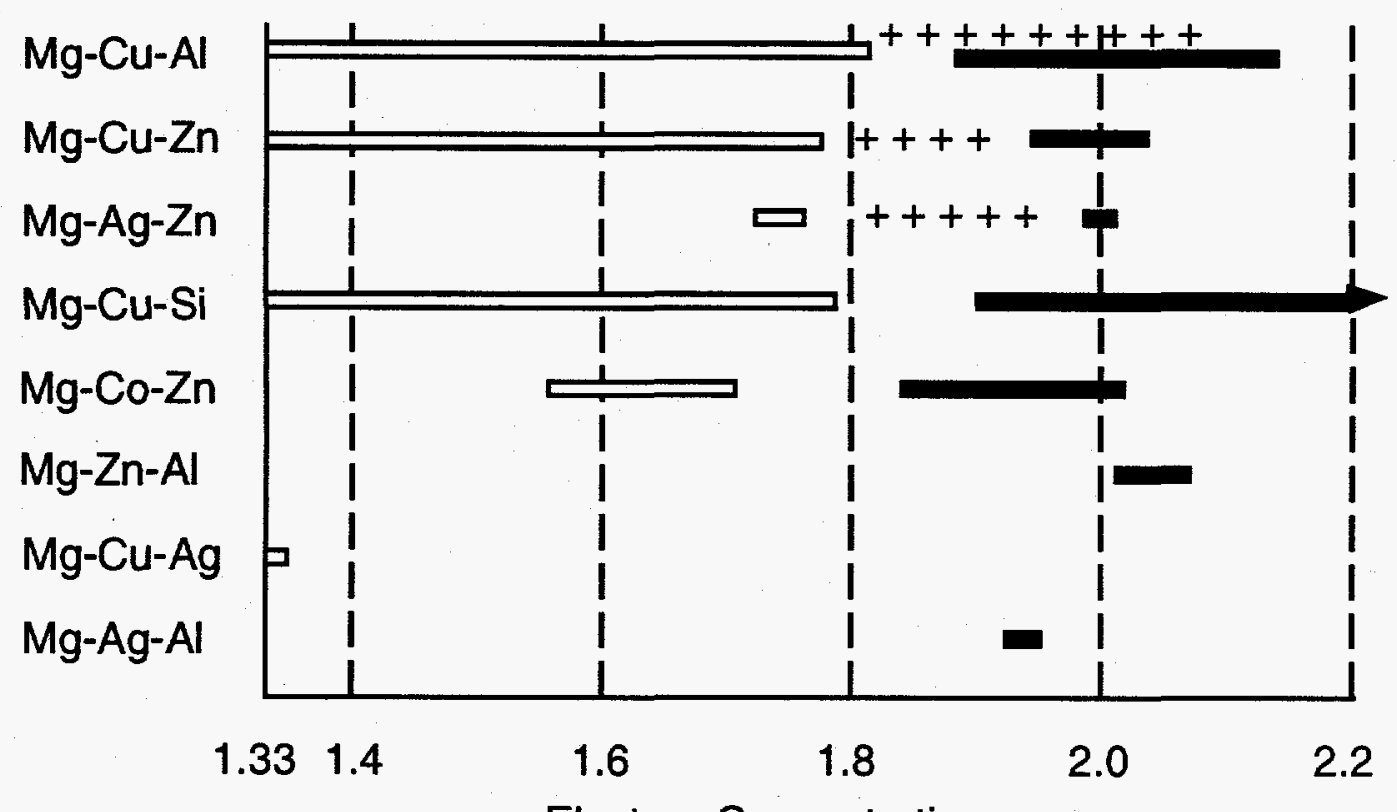

Electron Concentration

$\longrightarrow \mathrm{MgCu}_{2}$ type $(\mathrm{C15})=\mathrm{MgZn}_{2}$ type (C14)

$+++++\mathrm{MgNi}_{2}$ type (C36)

Fig. 1 Effect of valence electron concentration on phase stability for several ternary Mg-based Alloys [reproduced after Ref. 1]

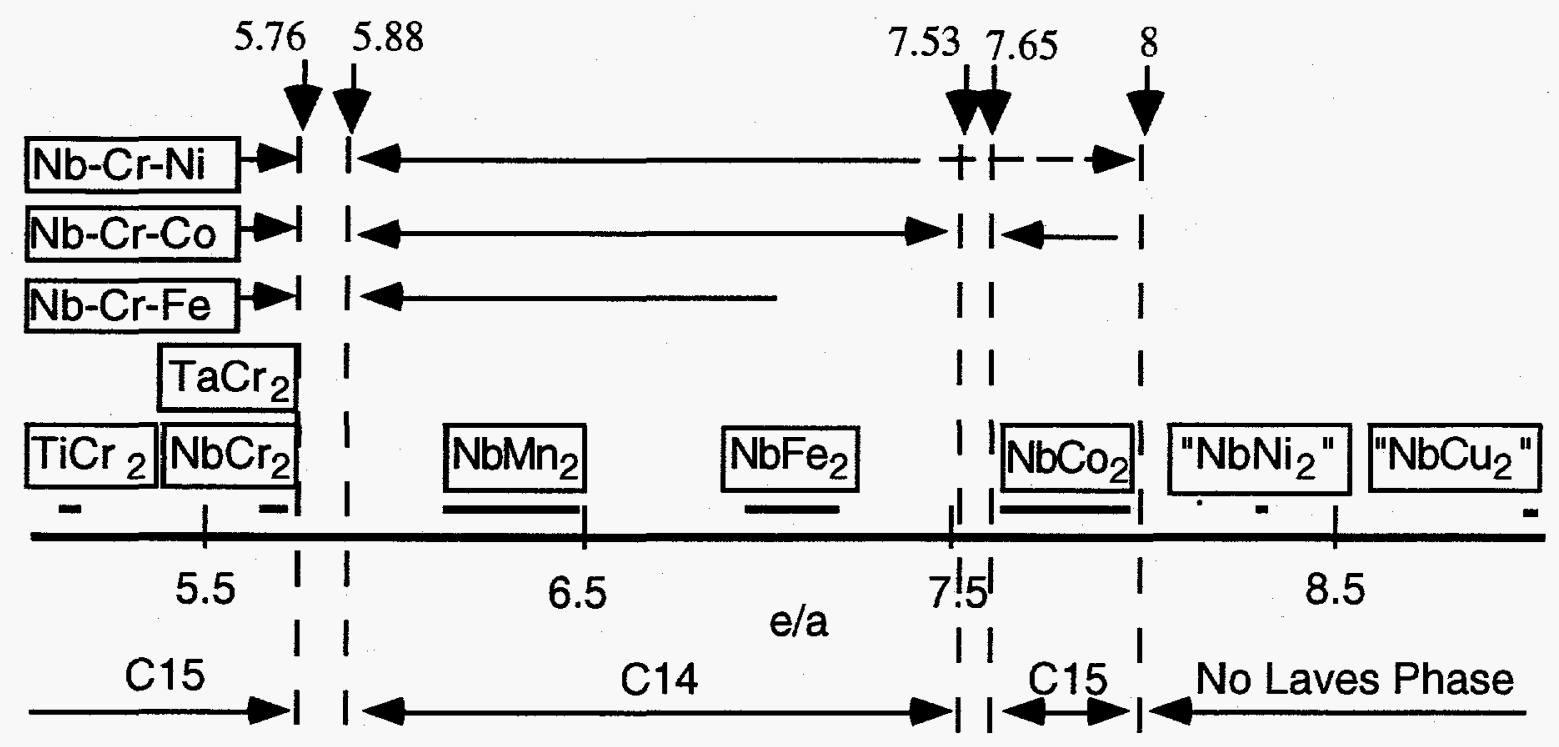

Fig. 2 Effect of average electron concentration (e/a) on phase stability in binary and ternary $\mathrm{NbCr}_{2}$-based systems 


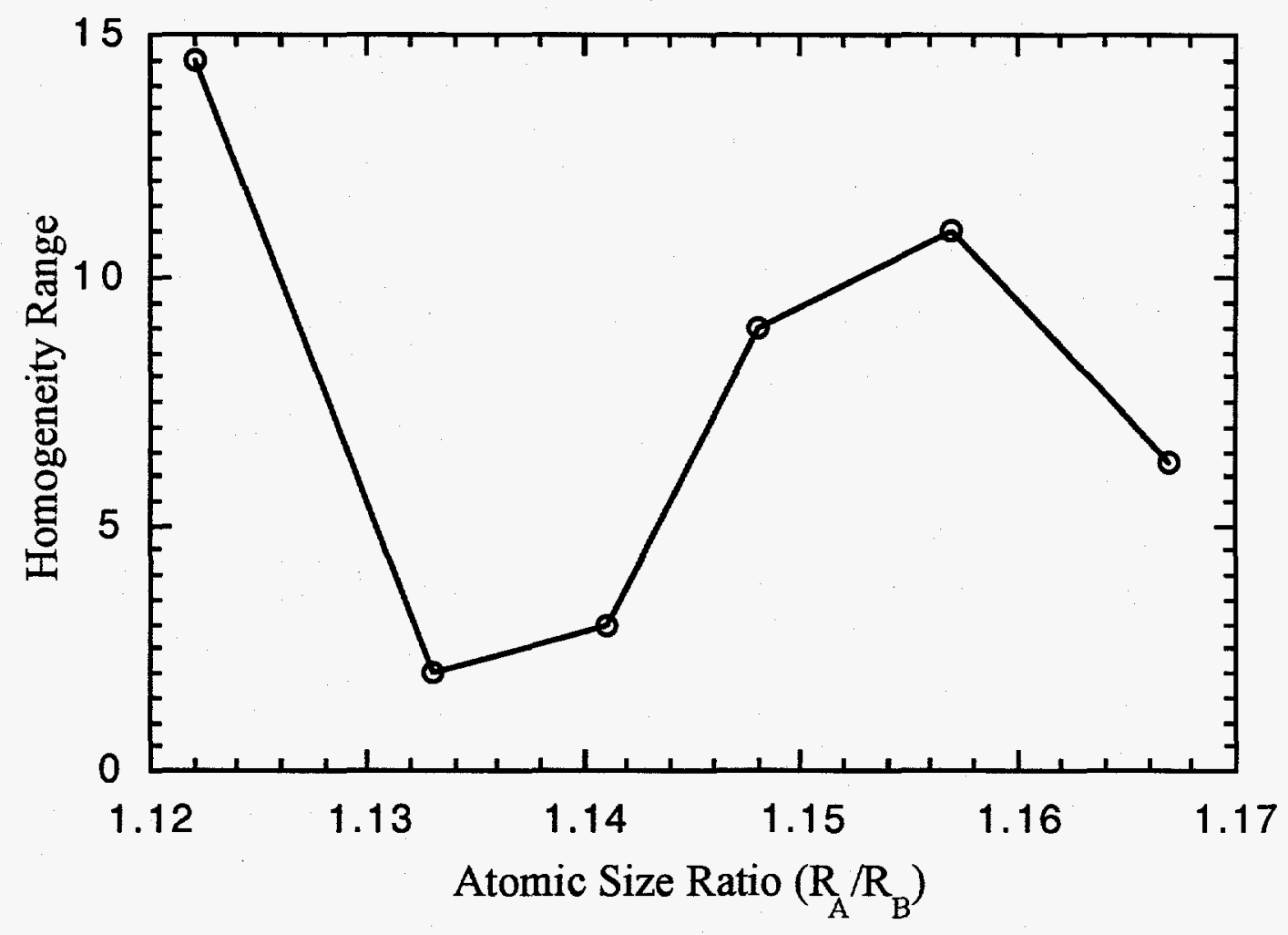

Fig. 3 Effect of $R_{A} / R_{B}$ ratio on the solubility range of binary Laves phases

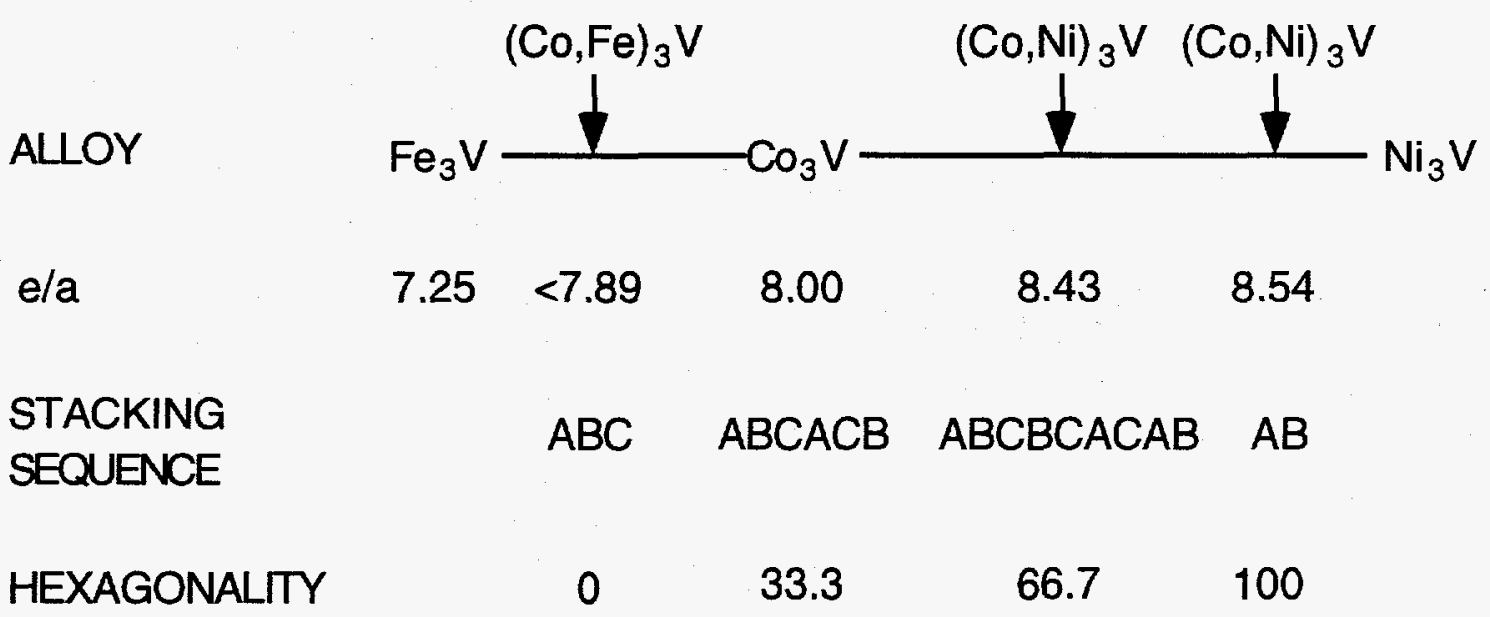

Fig. 4 Effect of average electron concentration (e/a) on ordered structures in pseudo-binary $\mathrm{Ni}_{3} \mathrm{~V}-\mathrm{Co}_{3} \mathrm{~V}$ and $\mathrm{Co}_{3} \mathrm{~V}-\mathrm{Fe}_{3} \mathrm{~V}$ systems [Reproduced after Ref. 20] 


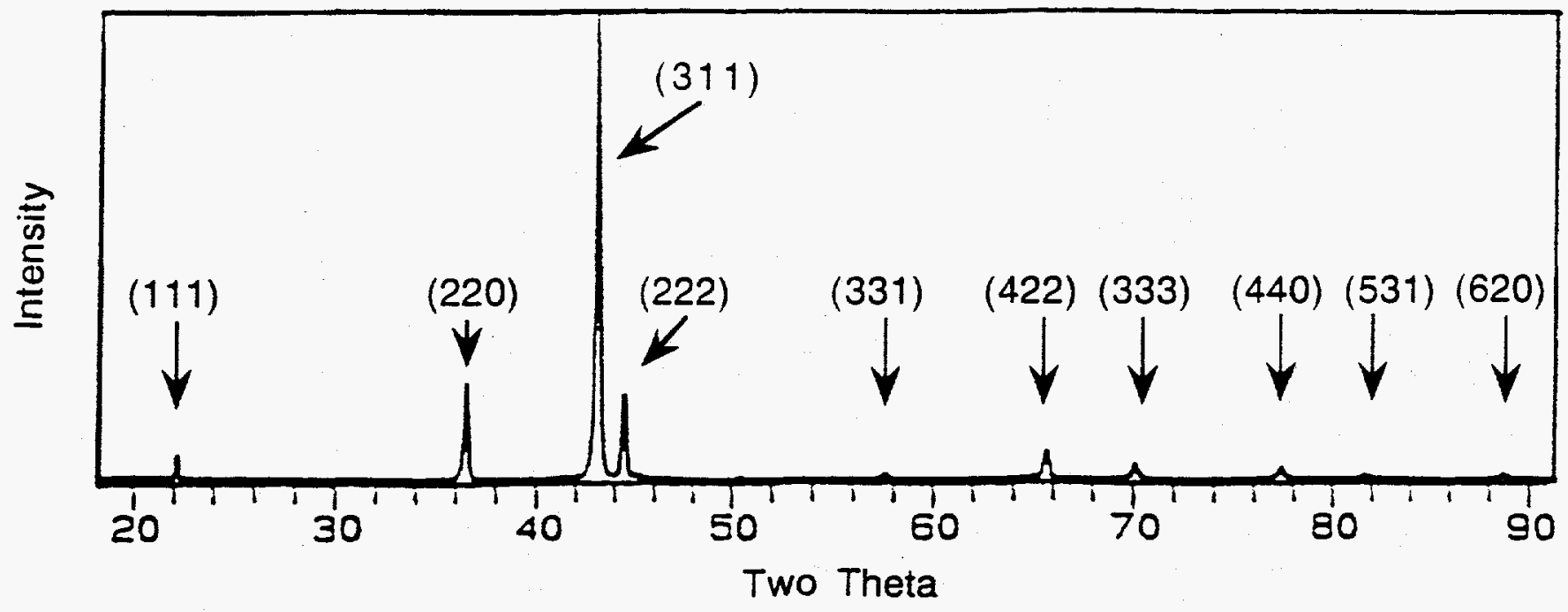

Fig. 5 X-ray diffraction pattern of the $\mathrm{Nb}-61.6 \mathrm{Cr}-5 \mathrm{Cu}$ alloy, indexed as the $\mathrm{C} 15$ structure 


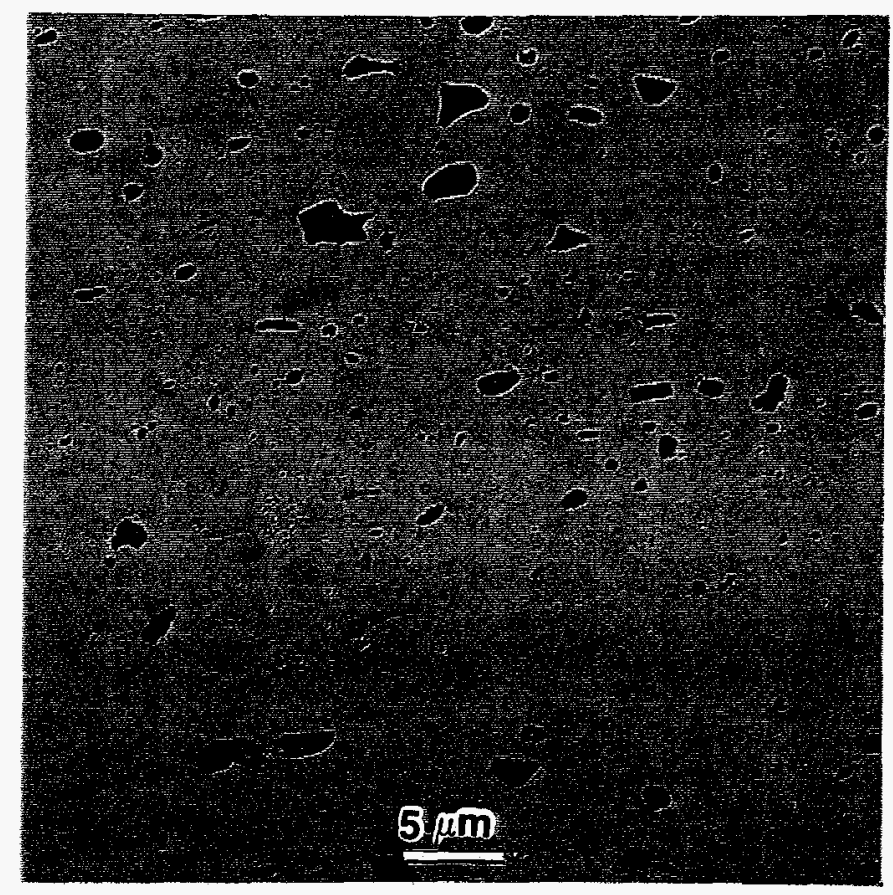

(a)

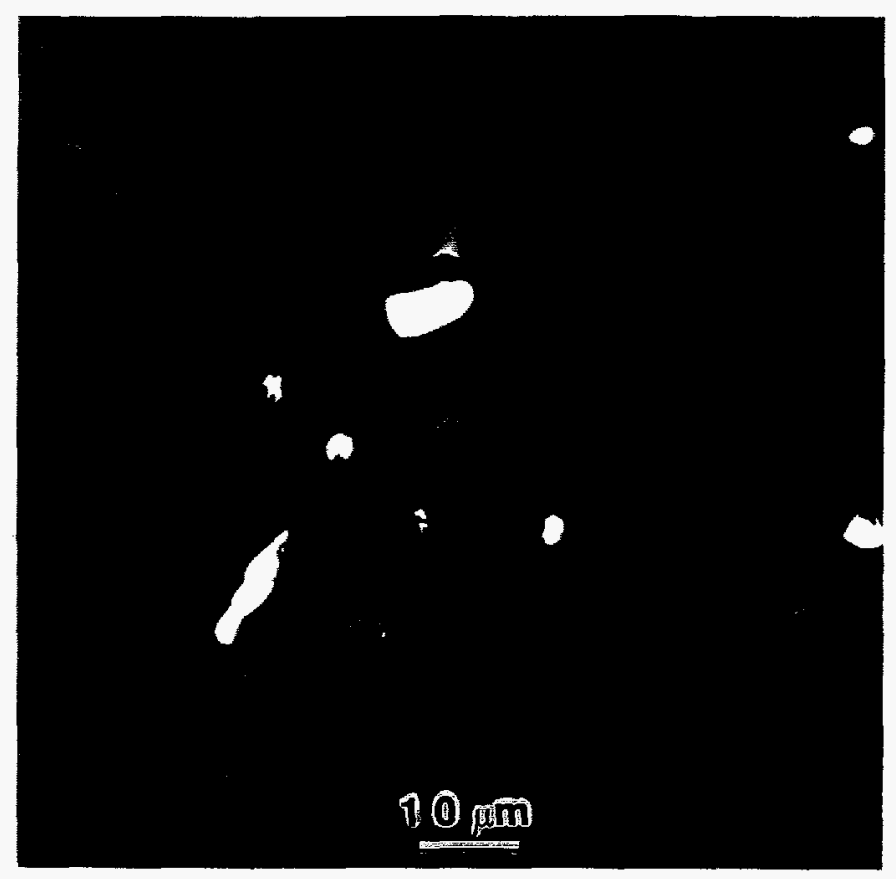

(b)

Fig. 6 Microstructure of the $\mathrm{Nb}-61.6 \mathrm{Cr}-5 \mathrm{Cu}$ alloy, as-polished condition, (a) optical micrograph with polarized-light; (b) back-scattering electron micrograph. Phases $1,2,3$ and 4 are Laves phase, $\sigma$-phase, $\mathrm{Cu}$ and $\mathrm{Nb}$ solid solutions, respectively. 
AIR PRODUCTS AND CHEMICALS

P.O. Box 538

Allentown, PA 18105

S. W. Dean

ALBERTA RESEARCH COUNCIL

Oil Sands Research Deparment

P.O. Box 8330, Postal Station F

Edmonton, Alberta

Canada T6H5X2

L. G. S. Gray

\section{ALLISON GAS TURBINE DIVISION}

P.O. Box 420

Indianapolis, IN 46206-0420

P. Khandelwal (Speed Code W-5)

R. A. Wenglarz (Speed Code W-16)

\section{AMAX R\&D CENTER}

5950 McIntyre Street

Golden, CO 80403

T. B. Cox

ARGONNE NATIONAL LABORATORY

$9700 \mathrm{~S}$. Cass Avenue

Argonne, IL 60439

W. A. Ellingson

ARGONNE NATIONAL LABORATORY-WEST

P.O. BoX 2528

Idaho Falls, ID 83403-2528

S. P. Henslee

\section{BABCOCK \& WILCOX}

Domestic Fossil Operations

20 South Van Buren Avenue

Barberton, $\mathrm{OH} 44023$

M. Gold
BRITISH COAL CORPORATION

Coal Technology Development Division

Stoke Orchard, Cheltenham

Glocestershire, England GL52 4ZG

J. Oakey

CANADA CENTER FOR MINERAL \& ENERGY TECHNOLOGY

568 Booth Street

Ottawa, Ontario

Canada K1A OG1

R. Winston Revie

Mahi Sahoo

COLORADO SCHOOL OF MINES

Department of Metallurgical Engineering

Golden, CO 80401

G. R. Edwards

DOE

DOE OAK RIDGE OPERATIONS

P. O. Box 2008

Building 4500N, MS 6269

Oak Ridge, TN 37831

M. H. Rawlins

DOE

DOE OAK RIDGE OPERATIONS

P. O. Box 2001

Oak Ridge, TN 37831

Assistant Manager for

Energy Research and Development

DOE

IDAHO OPERATIONS OFFICE

P. O. Box 1625

Idaho Falls, ID 83415

J. B. Malmo

\author{
BETHLEHEM STEEL CORPORATION \\ Homer Research Laboratory \\ Bethlehem, PA 18016 \\ B. L. Bramfitt \\ J. M. Chilton
}


DOE

Federal Energy Technology Center 3610 Collins Ferry Road

P.O. Box 880

Morgantown, WV 26507-0880

R. C. Bedick

D. C. Cicero

F. W. Crouse, Jr.

R. A. Dennis

N. T. Holcombe

W. J. Huber

T. J. McMahon

J. E. Notestein

\section{DOE}

OFFICE OF FOSSIL ENERGY

FE-72

19901 Germantown Road

Germantown, MD 20874-1290

F. M. Glaser

\section{DOE}

OFFICE OF BASIC ENERGY SCIENCES

Materials Sciences Division

ER-131 GTN

Washington, DC 20545

H. M. Kerch

DOE

Federal Energy Technology Center

626 Cochrans Mill Road

P.O. Box 10940

Pittsburgh, PA 15236-0940

A. L. Baldwin

G. V. McGurl

L. A. Ruth

T. M. Torkos

EC TECHNOLOGIES INC.

3614 Highpoint Drive

San Antonio, TX 78217

D. J. Kenton

ELECTRIC POWER RESEARCH INSTITUTE

P.O. Box 10412

3412 Hillview Avenue

Palo Alto, CA 94303

W. T. Bakker

J. Stringer
EUROPEAN COMMUNITIES JOINT

RESEARCH CENTRE

Petten Establishment

P.O. Box 2

1755 ZG Petten

The Netherlands

M. Van de Voorde

FOSTER WHEELER DEVELOPMENT

CORPORATION

Materials Technology Department

John Blizard Research Center

12 Peach Tree Hill Road

Livingston, NJ 07039

J. L. Blough

IDAHO NATIONAL ENGINEERING

LABORATORY

P.O. Box 1625

Idaho Falls, ID 83415

A. B. Denison

R. N. Wright

LA WRENCE BERKELEY LABORATORY

University of California

Berkeley, CA 94720

Ian Brown

LAWRENCE LIVERMORE NATIONAL

LABORATORY

P.O. Box 808, L-325

Livermore, CA 94550

W. A. Steele

LEHIGH UNIVERSITY

Materials Science \& Engineering

Whitaker Laboratory

5 E. Packer Avenue

Bethlehem, PA 18015

J. N. DuPont

NATIONAL MATERIALS ADVISORY BOARD

National Research Council

2101 Constitution Avenue

Washington, DC 20418

K. M. Zwilsky 
OAK RIDGE NATIONAL LABORATORY

P.O. Box 2008

Oak Ridge, TN 37831

P. T. Carlson

G. M. Goodwin

F. D. Johnson (5 copies)

R. R. Judkins

C. T. Liu

C. G. McKamey

J. H. Schneibel

V. K. Sikka

R. W. Swindeman

P. F. Tortorelli

M. R. Upton

I. G. Wright

PACIFIC NORTHWEST LABORATORY

P. O. Box 999, K3-59

Battelle Boulevard

Richland, WA 99352

R. N. Johnson

\section{SHELL DEVELOPMENT COMPANY}

WTC R-1371

P.O. Box 1380

Houston, TX 77251-1380

W. C. Fort

THE JOHNS HOPKINS UNIVERSITY

Materials Science \& Engineering

Maryland Hall

Baltimore, MD 21218

R. E. Green, Jr.
UNION CARBIDE CORPORATION

Linde Division

P.O. Box 44

175 East Park Drive

Tonawanda, NY 14151-0044

Harry Cheung

UNIVERSITY OF WASHINGTON

Department of Materials Science

and Engineering

101 Wilson, FB-10

Seattle, WA 98195

T. G. Stoebe

UNIVERSITY OF TENNESSEE AT

KNOXVILLE

Materials Science and Engineering

Department

Knoxville, TN 37996

P. Liaw

C. D. Lundin

WEST VIRGINIA UNIVERSITY

Department of Physics

Morgantown, WV 26506-6315

B. R. Cooper

WESTERN RESEARCH INSTITUTE

365 N. 9th Street

P.O. Box 3395

University Station

Laramie, WY 82071

V. K. Sethi

THE MATERIALS PROPERTIES COUNCIL, INC.

United Engineering Center

345 E. Forty-Seventh Street

New York, NY 10017

M. Prager

THE TORRINGTON COMPANY

Advanced Technology Center

59 Field Street

Torrington, CT 06790

W. J. Chmura 